\title{
The Development Teaching of Writing Fable Text Module with Project Based Learning (PjBL) Containing Characters
}

\author{
Vivi Indriyani \\ Master Program of Indonesia Language Education \\ Universitas Negeri Padang \\ Padang, Indonesia \\ Email: vivi.indriyani93@gmail.com
}

\author{
Syahrul Ramadhan \\ Faculty of Language and Art \\ Universitas Negeri Padang \\ Padang, Indonesia \\ Email: Syahrul_810@yahoo.com
}

\begin{abstract}
The research aims to describe the process of developing the project based learning module to the material of the fable text which in valid, practical, and effective. This type of research is research development. The development of model whice is used model 4-D which consists of four stages (define, design, develop, and disseminate). The result of this research show that the teaching of writing fable text module with PjBL containing characters is valid, practical and effective. The score of the module validation given by the expert was $95,12 \%$ (very valid). The score of the module practicallity given by the teacher was $93,05 \%$ (very practical). The score of the module practicallity given by the students was $85,17 \%$ (very practical). The score of the module practicallity given by student activity was $91,3 \%$ (very active). The score of the effectiveness of the module based on the students learning achievement in writting fable text was 86 or A (very effective). The score of the effectiveness of the module based on the students learning achievement in knowledge fabel text was 88,3 or $A$ (very effective). Furthermore, the score of the effectiveness of the module based on the result of assesment on the student attitute was 92,6 or $A$ and characters was $92,21 \%$ or $A$ (very effective).
\end{abstract}

Keywords—development; module; fable; project based learning (PjBL); character

\section{INTRODUCTION}

The text fable stories is a type of literary text. The goal of literary learning at each and every level of school is basically the same, it's just that there is a difference in pressure with respect to the type and level of school, that is to growing a language skills. That literary teaching can help education as a whole if the scope includes four benefits, those are helping language skills, improving cultural knowledge, developing inventiveness and taste, and support the formation of character [1].

Based on these goals, it is important for students to learn the text fable stories. The ability in literature (including fable text) has the main function of refining the character, improving humanity, and social awareness, cultivating cultural appreciation and distributing ideas, imagination and expression constructively both oral and written. There is an emphasis that learning animal stories (fable text) is not just transferring the knowledge of teachers to their students, but rather aimed at adding or sharpening the students' sensitivity, emotionally, imaginatively, and aesthetically [2].

Learning to use fable stories is not suitable for teens because the characters in the story are animals. Nonetheless, thaditional literature has other subgenres, such as folk tales [3]. However, I think in learning using fable story is very good to convey the moral value contained in the story. The moral value in fable text are mode easily understood than the folk tales.

The finding on the field show that the ability to write text fable story of students is still low. This is proved through interviews, students writing skill, and student text analysis. Based on these facts obtained the information about the low students score in writing fable stories. The matters found are as follows. First, text-based Indonesian language learning is based on the structure and linguistic text, learning based on it is a new type in Indonesian language learning. Therefore, teachers find the difficulties in finding references to complete the teaching materials. Second, the source of learning used in learning to write texts fable stories is only a book published by Kementrian Pendidikan dan Kebudayaan (Kemendikbud). Other than that book, no other learning resources were used for this text-writing lesson, so that the teaching materials used by teachers are not vary. Third, the learning model or the teaching approach applied by the teacher has not varied. The approach used in learning is the scientific approach. The approach used is not well realized, the teacher is still a center of learning and only a few students are actively participating.

Based on these problems, the most fundamental things related to the learning resources used by students. The problems are as follows. First, textbooks used by students are still lacking in the description of the material, so teachers still have to prepare additional materials for teaching. Second, the source of learning from the internet can not be trusted completely, there should be supervision from the teacher to avoid misunderstanding. Third, based on the attractiveness of the book, the appearance of the book is less interesting, in terms of the images and colors used. Fourth, another book is needed to support learning. 
Based on the problems described above, the completion can be implemented is developing a learning resource that can be used to support the use of the main book, one of which is the source of learning made by the teacher. This is in accordance with Permendiknas cited as follows.

In PP number 19 of 2005 Clause 20, it is suggested that teachers are expected to develop learning materials, which is then confirmed through the Regulation of the National Education Minister (Permendiknas) number 41 of 2007 about Process Standards, which among others regulates the learning process planning which requires for teachers in the education unit to develop a lesson plan (RPP). One of the elements in RPP is learning resources. Thus, teachers are expected to develop teaching materials as one source of learning [4].

Teachers should be able to create teaching materials that are easy to understand and attract to students. These teaching materials can develop students' thinking ways to be more creative and innovative. Teachers should not focus on textbooks. In addition to textbooks, other teaching materials that teachers can create are modules. Inside the module, there are steps of learning activities that students can follow and do in a structured way. Through the module, students can perform activities independently. The teacher's role as a facilitator can be done well. In addition, learning using modules can help students to learn independently at home. This is due to the usage instructions contained in the module. This module serves as a complement to the student textbook.

The learning module of writing fable texts is prepared in accordance with the principles of module preparation, module characteristics, module elements, module structure, and module compilation stage. The learning module of writing fable texts was developed based on project based learning $(\mathrm{PjBL})$. The concept of $\mathrm{PjBL}$ is in line with scientific approaches and text-based learning. Thus, the PjBL used as the basis for the module developing requires the learning of fable text writing which can be implemented independently with the steps and conditions that have been established. Project-based learning affords "students the possibility and the motive to work their way to the solution in their own idiosyncratic way" [5]. In this way, the learners' prior knowledge and experience may be activated through engaging tasks and opportunities for collaboration designed to shape and direct new understandings. This is balanced, however, with a flexible instructional design; learners are granted considerable freedom to decide what and how to learn [6].

Project Based Learning is an individual or group activity that goes on over a period of time, resulting in a product, presentation, or performance. It typically a time line and milestones, and other aspect of formative evaluation as the project proceds [7]. PjBL suggests learning objectives serve as guidelines to facilitate understanding of content-related knowledge, but also grants considerable freedom to learners to achieve these objectives; further, through individual and collaborative study, students' learning may differ from the stated course objectives [8]. The essential design elements of a project include: a project overview and rationale; a set of clearly defined learning objectives and key concepts; a list of materials and resources; a set of enabling tasks; and assessment criteria and rubrics [8].

Research using a project based learning model has been widely practiced. However, the research is mostly done on science, technology, engineering and mathematic (STEM), while language learning is rarely done. Previous research results show that effective project based learning is used for learning [9] [10] [11] [12] [13]. This literature analysis uncovered that students in post-secondary courses were experiencing a range project based learning activities in a variety of science, technology, engineering and math classrooms. Most students' opinion was positive towards the achievement of content knowledge, interdisciplinary skills, and the use of PjBL in their courses [9]

The project-based learning model affects the students creative thinking ability [10]. Studies have proven that when implemented well, project-based learning results positive outcomes related to students' learning in the areas of content knowledge, collaborative skills, engagement and motivation, and critical thinking and problemsolving skills [11]

Project-based learning $(\mathrm{PjBL})$ has been promoted as an effective and frequently used student-centered learning approach for various learning environments [12]. The PjBL alse enchances the cognitive and critical thinking. The use of PjBL module enables strudent to plan their project easily, work collaboratively with peers with minimal supervision from supervisors or lectures and succesfully complete their project in time. The positive feedback from this study may me used by management to furter apply this PjBL concept across disiplines and departments [13].

Project based learning (PjBL) used as a basis for compiling this learning module is structured based on seven steps. Therefore, the seven steps are used as the foundation in preparing the module of learning to write fable text. The seven steps include determining the fundamental questions, determining the project, preparing the project plan, preparing the project implementation schedule, project implementation with facilitation and monitoring of teachers, preparation of reports and presentations, and evaluation of project and project outcomes.

Project based learning (PjBL) can be applied in various fields. Application of $\mathrm{PjBL}$ is intended for students to produce the product. In this study, the product is a fable text. PjBL is assumed to be appropriately used in the development of learning fable text writing modules. PjBL learning is expected to enable students to produce products in the form of text. The written text if a product of a collection fable texts can motivate students to write. It can also be read by other students. In addition, $\mathrm{PjBL}$ in providing students the opportunity to manage their own activities or activities to complete the task of training students become independent.

One of the results of the study showed that the learners showed significant progress in reading and writing when asked to study and analyse the reading sources related to the topic of their proposed research in order to design their own technological products each having its specific characteristics and novelty at the present stage [14]. 
Learning module of writing fable text based on project based learning $(\mathrm{PjBL})$ then integrated with character education values. That is, the developed learning module contains character education. Character education is generally conducted through action, modeling, familiarizing moral attitudes according to the norms prevailing in society.

Character education has been a concern of the government long time before. In Act No. 20 of 2003 on National Education System in clause 1 (one) among others stated that education is a conscious and planned effort to create an atmosphere of learning and learning process so that learners are actively developing their potential to have spiritual spiritual power, self controlling, intelligence, precious character, and skills needed for himself, society, nation, and country. In addition to the Law, positive characters are also widely written in the vision and mission of educational institutions. In general, educational institutions form a vision that is not only charged to make graduates smart but also [15].

In the learning of fable text itself, of course there is a character education content. In this case, students know that through learning the text of fable stories students can know and live a good attitude and moral. It is in accordance with the essence of the text itself that the text of fable stories is a story text containing moral teachings that contain stories depicting human nature. So that the texts that are studied are examples of instructional applications containing the character education itself. It can be seen in the sample text that is read and written by the students. "Fabel, from the latin fabula, means 'discorse' or 'tale'. This definition apologue, tale in which a small truth is hidden; a moral under the veil of a fiction. "That is, the fable text is a text containing the moral teachings contained in fiction [16].

The animal figures that exist on moral values have a character like human. Their characters are good and some are not good. They have an honest, polite, ingenious, happy, friendly, and always commendable deed. Vice versa, they also have the character of cunning, arrogant, greedy, like cheating and want to win alone. However, in general at the end of the story there are changes in the behavior of the characters and the mandate that can be obtained from the moral story [17].

It is impossible that text contained about moral teaching, capable of building reader character. The reader may experience a misinterpretation of the text he or she reads. The understanding of the text should be supported by raising some aspects, those are (1) awareness of the inner demands experienced by the fables figures, (2) the moral sensitivity that can be learned from the story, (3) reasoning about the possible actions of the fable figures, (4) the motivation of moral action, (5) consciousness of sacrifice for the greater kindness, (6) continuation of the moral sensitivity in the fable figures, and (7) moral conclusions obtained at the end of the story [18]. Fables can be a convenient means of morality. The assumption that the process of moral education is boring can be overcome through fables [19].

In project based learning based learning ( $\mathrm{PjBL}$ ) there is also a character education content. Character arising from project based learning (PjBL) is very useful to students for their life, especially in doing the job [20] [21]

$21^{\text {st }}$ Century employers are looking for graduates who possess soft skills that include responsibility, self-confidence, social and communication skills, flexiblity, team-spiritedness, good work attitude, self-motivation and self-management. Many skills learned through project-based learning are highly sought by today's employers including the ability to work well with others, handle interpersonal conflicts, make thoughtful decisions, as well as practise and solve complex problems [20].

PjBL are, only one elements in the lecturer's personal teaching tool kit. We could try to develop some space within our own teaching to explore alternative approaches to learning with our students. Here, in this personal and safe space, we can try to enhance our students' learning experiences, and help them to develop and articulate the employability skills and attributes which are demanded of them in the "real" world [21].

Based on this, many characters are formed in project based learning $(\mathrm{PjBL})$. The characters that are targeted in this lesson are limited to honest, disciplined, and responsible characters. The honest attitude shows that the task is written based on self-generated ideas, not looking from other sources, or having other students, it is intended that the students produce their own writing. The attitude of discipline is an orderly behavior and obedient to various rules and regulations. It is in accordance with project based learning (PjBL) that the implementation is based on the steps and adjusted to the time set. If the student is not disciplined, the product will not be completed on time. Responsibility is the attitude and behavior of a person to carry out his duties and obligations, which he should do. In writing the text, the student must be responsible for the writing that is made, because the text of moral / fable is the text of the moral story, so that the text must contain good moral value to be taken wisahnya for people who read.

After the project work students knew that being a team member entailed certain obligations, most of them developed skills for solving in-group conflicts, and learned to be responsible in relation to the roles assigned to them. Most importantly, all students, regardless of language performance, or motivational intensity seemed to have developed their cooperative skills [22].

Everything that happens to man is the act of his character. A person can succeed or fail because of his character. The current young generation needs to implement character education in the context of everyday education [23]. One of them is that it can be implemented in learning, so it can optimize the development of all dimensions, namely cognitive, physical, social-emotion, creativity, and spiritual. The quality of the student becomes superior not only in the cognitive aspect, but also in its character.

With textbook/fable learning module in learning based project based learning (PjBL), character education is integrated holistically in any instructional or action steps. In addition, presentation of module contents, presentation of materials, illustrations, drawings, and supporting info, and 
examples of the text presented contain character education. That is, through a learning module to write fable text stories based project learning (PjBL), students obtain the competence of character education.

Modules that are characterized by character education can have an effect on the improvement of student character. The results showed that the thematic and innovative modules characterized on the theme of environmental pollution can have an effect on the positive character of the students, especially on the character of environmental care, curiosity, confidence, communicative, independent, and anthusiasm of reading [24].

Based on the reality, it is important to develop teaching materials in the form of learning module of writing fables text based on project based learning $(\mathrm{PjBL})$ characterized by character education. With the presentation of materials and steps of structured activities, students are expected to more quickly get the concept and being able to write the fable text well. This module is expected to provide solutions for students who are difficult to fable text. This module is also expected to develop students' creativity and innovation in learning. In addition, this learning module can make students understand the character education and can apply in their life.

Based on the background of the issues raised, the problem formulated in this research is as follows. How is the process of developing teaching of writing feble text module with project based learning $(\mathrm{PjBL})$ containing characters valid (in terms of content, presentation, language and graphics), practical (in terms of ease to use and conformity with time) and effective (seen from student activities, learning outcomes, and affective students).

\section{METHODS}

Module development model which is conducted using 4$\mathrm{D}$ model. The 4-D model has four development stages, those are defining, design, develop, and dessiminate. This development research used the 4D (four-D model) model. The development process is define, design, development, and dessiminate [25].

The defining phases begin from the initial preliminary analysis, student analysis, task analysis, concept analysis, and the formulation of learning objectives. In this definition stage is done determination of learning requirements by analyzing the competency standards and limitations of learning materials that will be taught by teachers based on the contents of the curriculum. The design phase aims to create a learning module to write text fable story based on project based learning character education. Modules are prepared in accordance with core competencies, basic competencies, indicators, and learning objectives. The development stage aims to produce a modified form of learning module according to the validator's suggestion, so as to obtain the final form of module that can be used in the trial. This stage consists of the validity, practicality, and effectiveness of the module. The disseminate is the stage of product use that has been developed on a wider scale, for example in other classes.
The type of data in this research is quantitative data obtained from questionnaires and learning outcomes and qualitative data from interviews and observation sheets. The subjects of the experiment are the students totaling 30 people. Data analysis technique used is descriptive data analysis technique. Descriptive analysis technique is conducted by using descriptive statistics.

\section{DISCUSSION}

Based on the result of the research, it can be concluded that the learning module of writing fable text based on project based learning has character education is valid, practical, and effective. Analysis of test data can be explained through four stages of definition, define, design, development, and dessiminate.

Based on the results of the final analysis of beginning and end, it can be explained as follows. First, learning is still teacher-centered. Second, the source of learning used by students is only one of the book packages provided from the government. Third, teachers do not make their own teaching materials, because the material to be taught is already in the package book. Fourth, the books available in the library have not much to do with the text of moral/fable stories. Fifth, the learning approach used by teachers is based on guidelines for the preparation of lesson plans.

Based on the results analysis to student, it can be concluded that students need learning resources according to their characteristics, both in terms of the use of letters, images, color combinations, to the use of communicative language. One learning resource that can be used is a learning module. The learning module must be in accordance with the needs of students, and generate student motivation to learn.

Based on curriculum analysis, modules developed based on KI-3 and KI-4, KI-3.2 and KI-4.2. The description of the material concept of writing a fable text consists of two. First, the deepening of the concept, consisting of deepening the concept, the meaning and purpose, the characteristics, the structure of fable text, and compare fable text with other texts (short story text). Details of the concept aims to provide students with an initial understanding the nature of fable texts. Second, compile (write) a fable text. The concept of learning materials in this section is the steps to write a fable text. In this section, students write based on elements of fable text in the form of background, plot, and figure. In addition, students must apply their knowledge of the concept of fable texts. The purpose of this learning is that students are able of fable texts.

After defining, the next activity is designing the learning module. The design consists of compiling the module framework and writing the module draft. After the define and design stage is completed, then the development stage (develop). Development is done to test the draft module that has been prepared. The activities undertaken at this stage consist of three, namely (a) validity test, (b) practicality test, and (c) effectiveness test. 
TABLE I. RESUlT OF MODUlE VALIDATION BY EXPERT

\begin{tabular}{|l|l|c|c|c|}
\hline No. & \multicolumn{1}{|c|}{ Rated Aspect } & Scores & Validity (\%) & Category \\
\hline 1. & $\begin{array}{l}\text { Eligibility of } \\
\text { module content }\end{array}$ & 105,0 & 93,75 & $\begin{array}{c}\text { Very } \\
\text { valid }\end{array}$ \\
\hline 2. & Module language & 31,5 & 98,44 & $\begin{array}{c}\text { Very } \\
\text { valid }\end{array}$ \\
\hline 3. & $\begin{array}{l}\text { Module } \\
\text { presentation }\end{array}$ & 79,0 & 98,75 & $\begin{array}{c}\text { Very } \\
\text { valid }\end{array}$ \\
\hline 4. & Modul reliability & 28,0 & 87,50 & $\begin{array}{c}\text { Very } \\
\text { valid }\end{array}$ \\
\hline \multicolumn{2}{|l|}{ Module validation entirely } & 243,5 & 95,12 & $\begin{array}{c}\text { Very } \\
\text { valid }\end{array}$ \\
\hline
\end{tabular}

The practicality of the module consists of three kinds, the practicality of the module by the teacher, the practicality of the module by the students, and the student's learning activities. These three points are explained as follows. First, practicality by the teacher. The results of teacher practicality analysis can be seen in the following table.

TABLE II. DATA DESCRIPTION OF MODULE PRACTICALITY BY TEACHER

\begin{tabular}{|c|l|c|c|c|c|}
\hline No. & $\begin{array}{l}\text { Rated } \\
\text { Aspect }\end{array}$ & Scores & $\begin{array}{c}\text { Maximum } \\
\text { Scores }\end{array}$ & $\begin{array}{c}\text { Practicality } \\
\text { Value (\%) }\end{array}$ & Category \\
\hline 1. & $\begin{array}{l}\text { Ease of } \\
\text { Use }\end{array}$ & 56 & 60 & 93,33 & $\begin{array}{c}\text { Very } \\
\text { practical }\end{array}$ \\
\hline 2. & $\begin{array}{l}\text { Time } \\
\text { Used }\end{array}$ & 11 & 12 & 91,67 & $\begin{array}{c}\text { Very } \\
\text { practical }\end{array}$ \\
\hline \multicolumn{2}{|c|}{$\begin{array}{c}\text { Module } \\
\text { Practicality } \\
\text { Entirely }\end{array}$} & 67 & 72 & 93,05 & $\begin{array}{c}\text { Very } \\
\text { practical }\end{array}$ \\
\hline
\end{tabular}

Second, the module's practicality by students. The result of student's practicality analysis can be seen in the following table.

TABLE III. DATA DESCRIPTION OF MODUle PRACTICALITY BY THE STUDENS

\begin{tabular}{|c|l|c|c|c|}
\hline No. & Rated Aspect & Scores & Practicality Value & Category \\
\hline 1. & $\begin{array}{l}\text { The ease of } \\
\text { using }\end{array}$ & 1195,2 & 85,37 & $\begin{array}{c}\text { Very } \\
\text { Practical }\end{array}$ \\
\hline 2. & Time used & 252,7 & 84,23 & $\begin{array}{c}\text { Very } \\
\text { Practical }\end{array}$ \\
\hline \multicolumn{2}{|c|}{$\begin{array}{c}\text { Module Practicality } \\
\text { Entirely }\end{array}$} & 1447,9 & 85,17 & $\begin{array}{c}\text { Very } \\
\text { Practical }\end{array}$ \\
\hline
\end{tabular}

Third, student learning activities. Results of student activity analysis can be seen in the following table.

TABLE IV. DATA DESCRIPTION OF STUDENS LEARNING ACTIVITY

\begin{tabular}{|c|c|c|c|c|}
\hline No. & $\begin{array}{c}\text { Number of } \\
\text { Indicators }\end{array}$ & $\begin{array}{c}\text { Activity } \\
\text { Percentage }\end{array}$ & $\begin{array}{c}\text { Number of } \\
\text { Students }\end{array}$ & Category \\
\hline 1. & 7 & 100,00 & 27 & Very active \\
\hline 2. & 2 & 77,33 & 2 & Active \\
\hline 3. & 1 & 66,67 & 1 & Active \\
\hline \multicolumn{2}{|c|}{$\begin{array}{c}\text { Module Practicality } \\
\text { Entirely }\end{array}$} & 91,30 & 30 & $\begin{array}{c}\text { Very } \\
\text { Active }\end{array}$ \\
\hline
\end{tabular}

The effectiveness of learning modules can be seen student learning results. Students' learning results are assessed from three aspects: attitude, knowledge, and skills. Overall, it can be concluded that effective learning module to improve student learning results. The results of the analysis can be seen in the following table.

TABLE V. DATA DESCRIPTION OF STUDENS LEARNING RESULT

\begin{tabular}{|c|c|c|c|c|}
\hline No. & Learning Result & $\begin{array}{c}\text { The Average } \\
\text { Score }\end{array}$ & Score & $\begin{array}{c}\text { Change } \\
\text { Value }\end{array}$ \\
\hline 1. & Cognitive & 44,16 & 88,33 & $\mathrm{~A}$ \\
\hline 2. & Skills & 75,53 & 85,72 & $\mathrm{~A}$ \\
\hline 3. & Attitude & 8,33 & 92,60 & $\mathrm{~A}$ \\
\hline 4. & Character & 8,40 & 92,21 & $\mathrm{~A}$ \\
\hline
\end{tabular}

Based on the results of effectiveness, it can be concluded that learning module is effective in improving student learning results.

After testing, the learning module is revised again. Furthermore, the stage of dissemination (dissiminate). The deployment is conducted to test the school library. In addition, the module has been distributed to Indonesian language teachers. In this case, the teacher filled out the questionnaire of the module deployment. The statement in the questionnaire about the quality of the module and some alternative modules that can be deployed. Dissemination is also done to other Indonesian language teachers who are students of the Indonesian language Postgraduate Program Universitas Negeri Padang.

\section{CONCLUSIONS AND SUGGESTIONS}

Based on the discussion in this research, it can be concluded several things as follow. Some problems that obstruct the achievement of learning objectives to write the fable text, namely the limitations of teaching materials used. This has an impact on student learning results that still have an average under the minimum passing criteria. Therefore, it is designed one of the learning materials in the form of learning module to write of fable text based on project based learning as one solution to solve the problem. In this case, the preparation of learning concept in writing of fable text in the module is developed by applying the steps of project based learning implementation. In addition, the implementation process of project based learning contains character knowledge that is honest, disciplined, and responsible.

Module development process at design stage. At this stage the module framework is designed and drafting the module. The planning of the learning module framework consists at least of instruction manual, competence to be achieved, material content, exercises, and worksheets. Components are organized into three parts, namely the introduction, learning, and evaluation. At the drafting stage of the module, a module of learning is made based on the module framework.

At the development stage the following results are obtained. First, the learning module is to write of fable text based project based learning (PjBL) is characterized by highly valid character education. That way, the module can be tested. Second, the learning module of writing of fable text based 
project based learning (PjBL) is characterized by very practical character education. That way, the module has been used by teachers and students. Third, the learning module of writing fable text based on project based learning (PjBL) is characterized by highly effective character education to improve student learning outcomes.

After the module is declared valid, practical, and effective, then the module is distributed to the following party. First, Indonesian language teachers at test schools, libraries, and Indonesian language teachers in addition to test schools.

Based on the conclusions that have been described, there are suggestions submitted to related parties. The suggestions related to the learning module addressed to teachers, students, and researchers next. First, for teachers, through the development of this module, teachers are expected to be able to utilize the learning module of writing the story fable text based project (PjBL) character education as a model of teaching material development on Indonesian language learning materials Curriculum 2013, because the project model based learning ( $\mathrm{PjBL}$ ) in the module is relevant to scientific and text-based learning approaches to develop the competence of students' knowledge and competence, as well as to character education as the affective aspects of the students development.

Second, For students, the result of product development in the form of learning module in writing the story / moral text based on project based learning $(\mathrm{PjBL})$ is characterized by character education, it is expected to help students mastery the three competences (attitude, knowledge, and skill) on learning writing fable text. That is, through the module students are expected to master the competence in one practical step. The module is also expected to be used by students in each academic year to study the material of writing of fable text.

Third, for the next researcher, the results of this development research can be used as a comparison material or as a reference to consider and carry out good development research related to writing the fable text, project based learning $(\mathrm{PjBL})$, as well as character education.

\section{REFERENCES}

[1] B. Rahmanto, Metode Pengajaran Sastra. Yogyakarta: Pustaka Pelajar, 2008.

[2] A. Duski. "Nilai-nilai karakter bangsa pada buku kumpulan dongeng fabel karya Kevin Van Embis dan implmentasinya pada pembelajaran bahasa dan sastra Indonesia di SMP,” Jurnal Nosi, vol. 3, no. 1. pp. 1-11, 2015 .

[3] O. R. Erkaya, "Advantages of using translate stories from student' native language to teach EFL," The Journal of Language Teaching and Learning (JLTL), vol. 1, no. 2, pp. 57-66, 2011.

[4] Depdiknas, Panduan Pengembangan Bahan Ajar. Jakarta: Direktorat Jendral Pendidikan Dasar dan Menengah Direktorat Pembinaan sekolah Menengah Atas, 2008.

[5] L. Helle, P. Tynajala, \& Olkinoura, "E.Project-based learning in postsecondary education- theory,practice and rubber sling shots," Higher Education, 51, pp. 287-314, 2006.
[6] A. W. Bates \& G. Poole, "Effective teaching with technology in higher education, SanFrancisco, CA: Jossey-Bass, 2003.

[7] R. Donnelly \& M. Fitzmaurice, "Collaboration project — based learning and Problem-based learning in higher education: A consideration of tutor and student roles in learner-focused strategies, http://www.aishe.org/readings/2005-1/, 2005.

[8] H. Roessingh \& W. Chambers, "Project-based learning and pedagogy in teacher preparation: stalking out the theoretical mid-ground," International Journal of Teaching and Learning in Higher Education, vol. 2, no. 1, pp. 60-71, 2011.

[9] R. A. Ralph, “ Post secondary project-based learning in science, tecnology, engineering and mathematics, Journal of Technology and Science Education, vol. 6 (1), pp. 26-35, 2015.

[10] N. L. P. M. Marlinda, "Pengaruh model pembelajaran berbasis proyek terhadap kemampuan berpikir kreatif dan kinerja ilmiah," Singaraja: Universitas Pendidikan Ganesa, 2012.

[11] O. Widiastuti, “'E-exhibition' a framework of students' project based learning, Jurnal Linguistik Terapan, vol. 6, no. 2, pp. 63-67, 2016.

[12] F. Dag \& L. Durdu, "Pre-service teacher' experiences and views on project-based lerning process, International Education Studies, vol. 10, no. 7, pp. 18-39, 2017.

[13] Rahman et al, "Project based learning (pjbl) praktices at politeknik kota Bharu, Malaysia," Internasional Education Studies, vol 2, no. 4, pp. 140 148, 2009.

[14] Y. Y. Kovalyova, A. V. Soboleva \& A. T. Kerimkulov, “ Project based learning in teaching communication skills in english as a foreighn language to engineering students, iJET, vol. 11, issue 4, pp. 153-156, 2016.

[15] E. Mulyaningsih, "Analisis model-model pendidikan karakter untuk usia anak-anak, remaja, dan dewasa," https://scholar.google.com/scholar, 2011.

[16] W. Apriyani, G. Gunatama, M. S. Indtiani, "Analisis fakta dan sarana cerita dalam teks nilai moral fabel siswa kelas VIII A1 Singaraja," eJurnal. Jurusan Pendidikan Bahasa dan Sastra Indonesia, vol. 3, no. 1, pp. 1-10, 2015.

[17] A. C. Wolosky, "History as rhetoric, fable, and literary genre," International Journal of Literature and Arts, vol. 2, no.1, pp. 16-23, 2014.

[18] D. Narvaez, "Moral text comprehension implications for education and research," University of Notre Dame, USA: Jornal of Moral Education, vol. 30, no.1. pp 43-54, 2001.

[19] A. C. Henderson, "Having fun with the moralities: henryson's fable and late medieval fable innovation," Studies in Scoottish Literature, vol. 32: iss 1, pp 66-87, 2001.

[20] F. Musa, N. Mufti, R. A. Latiff \& M. M. Amin, "Project based learning (pjbl): including soft skill in $21^{\text {st }}$ century workplace," Procedia-Sosial and Behavior Sciences, vol. 59, pp. 565-573, 2011.

[21] G. Wood, "Voices from the field: developing employability skills for archaeological students using a project based learning approach," vol. 4, no. 1, pp. 100-108, 2016.

[22] I. Fragoulis, "Project-based learning in the teaching of english as a foreign language in greek primary schools: from theory to practice," English Language Teaching, vol. 2 no. 3, pp. 113-119, 2009.

[23] G. A. S. R. Dewi, N. M. Sulastri, N. N. Garminah, "Pengaruh pendekatan saintifik berbasis pendidikan karakter terhadap keterampilan membaca bahasa Indonesia Kelas V semester II," E-journal PGSD Universitas Ganesha, vol. 3, no.1, 2008.

[24] N. Izzati, N. Hindarto, S.D. Pamelasari, "Pengembangan modul tematik dan inovatif berkarakter pada tema pencemaran lingkungan untuk siswa kelas VII SMP,” Jurnal Pendidikan IPA Indonesia, vol. 2, no. 2, pp 183184,2013

[25] S. Thiagarajan, et.al., Instructional Development for Training Teacher ff Exceptinal Children: A Sourcebook. Indiana: Indiana University, 1974. 